\title{
nature
}

\section{A loss of vision}

Appropriations bills drawn up this summer suggest that Republicans in the House of Representatives have been paying little more than lip-service to the importance of a balanced science budget.

A nyone who thought that Washington had got the message about the importance of science funding, and had reached a bipartisan consensus on long-term federal investment in research, will have received a rude awakening in these few past weeks, as the US House of Representatives has considered the appropriations bills that will fund government spending in the next fiscal year.

The House appropriations bills, which are being drawn up under tight 'spending caps' negotiated back in 1997, are far from the last word in determining these funding levels for 2000 . But they still constitute the most explicit statement available of the priorities of this chamber of the Republican Congress.

Science and technology account for one dollar in seven of the socalled discretionary government spending that springs from the 13 appropriations bills. When Newt Gingrich was Speaker of the House, he instructed the appropriations subcommittees that basic science in particular was to be protected, even when money was tight. With Gingrich gone, however, some of these subcommittees appear to see science as a soft touch for reductions in funding.

At the Department of Energy, although House appropriators have supported non-weapons physics programmes, the proposed Spallation Neutron Source would get only a quarter of the money needed to begin construction. Plans for a new scientific simulation initiative at the energy department civilian laboratories would be shelved. (Across the whole government, in fact, the House cuts would eliminate most of the $\$ 360$ million information-technology research programme proposed in February by the Clinton administration).

Over at the commerce department, the House is seeking to eliminate the Advanced Technology Programme at the National Institute of Standards and Technology (NIST). Nor is there any money either for construction of a long-planned Advanced Measurement Laboratory at NIST.

The worst news for science, however, comes in the appropriations bill for Veterans' Affairs, Housing and Urban Development (VA/HUD), which, for complex historical reasons, includes funding for the National Science Foundation (NSF) and the space agency NASA. The NSF gets no increase at all from the VA/HUD bill passed by the appropriations committee (see Nature 400, 490; 1999). NASA is hit for $\$ 1$ billion in this bill, with space science cut 8 per cent from last year and Earth science programmes 16 per cent. According to a survey carried out by The Chronicle of Higher Education, each of these bills has also been larded with an unprecedented number of district-specific, pork-barrel research projects aimed at securing the bill's passage in a chamber where the Republicans hold the narrowest of margins.

The research agency missing from this status report is, of course, the National Institutes of Health (NIH). That's because NIH is in the appropriations bill for labour, health and education, to be drawn up by a subcommittee chaired by John Porter (Republican, Illinois). Porter's bill has been held back until last, while its total allocation has been subjected to recurrent raids by the other 12 appropriations bills that went before it, and now stands 20 per cent short of what its programmes cost this year.

That leaves the Congress facing an almighty budget crunch when it returns in September. It can either repeal the budget caps explicitly, fiddle the figures to find Porter's shortfall or implement massive cuts on politically popular programmes. Some predict that the caps will be bypassed before the new fiscal year begins on 1 October, and surging tax revenues are duly redirected to finance everyone's favourite programmes. But such a benign outcome looks increasingly elusive. The caps are, after all, the Republican party's main political achievement after four-and-a-half years in control of the Congress. And the demands for extra money have become so overwhelming that they are, overall, insatiable.

With the support of Porter and others, biomedical research may well find itself among the lucky few programmes whose demands are met when the dust settles. Thanks largely to choices by House appropriators, other science programmes will be less fortunate. That doesn't point to the balanced science policy recommended last year in a report from Vernon Ehlers (Republican, Michigan), deputy chairman of the house science committee, to his colleagues, as best serving the interests of the United States. Republicans who wish to restore the balance could start by amending the VA/HUD bill when the full House considers it after the summer recess.

\section{Summer-time blues}

\section{French researchers, angry and upset over last week's synchrotron decision, deserve a full explanation.}

$\mathrm{S}$ easoned French politicians are well aware that the best time for unpopular announcements is August, when virtually the whole country shuts down and goes on holiday. Claude Allègre, the embattled minister for national education and research, appears to be no exception. At least not to judge by the timing of last week's controversial announcement that France is to become a full partner in the construction and operation of a new $3-\mathrm{GeV}$ synchrotron facility, Diamond, being planned in Britain (see page 604).

There is much to commend this decision, even though it has angered a broad swathe of researchers - enthusiastically backed by local political leaders - who had been hoping to see their own proposed synchrotron, Soleil, built on French soil. Allègre is right to argue

that economies of scale alone make it sensible that large research facilities should increasingly be planned at a European level. They should not be seen as public-works projects to mop up local unemployment or to burnish the electoral prospects of local politicians.

But the critics, too, have their points. Collaborating with Britain will save on the short-term costs of building two separate machines; but longer-term savings are more questionable. And many French researchers face the substantial costs of travelling hundreds of miles to carry out experiments that others will be able to do on their doorstep. Allègre owes his critics a full and detailed description of the calculations behind his decision. This is unlikely to placate them; but it may show that the decision has more logic than many now accept. 